\title{
ОСОБЛИВОСТІ ФОРМУВАННЯ ПОПИТУ У МОДЕЛЮВАННІ ЛАНЦЮГІВ ПОСТАВОК ЗЕРНОВИХ КУЛЬТУР
}

\begin{abstract}
Інтенсивний розвиток аграрного сектору України за останні спричинив зміни у логістиці зернових культур. Попит на зерно та пов'язану з ним діяльність формує попит на його транспортування. Оцінити попит на сільськогосподарські перевезення необхідно для аналізу транспортної політики та прийняття рішень про господарську діяльність перевізників.

У статті розглянуто особливості формування попиту у моделях транспортування зернових культур вітчизняних науковців.

Імітаційна модель дозволяє визначити параметри автомобільного парку для вивчення попиту на транспортні перевезення сільськогосподарських товарів, на основі оцінки заявок на перевезення, що може бути використаним на етапі транспортування «індивідуальне сільське господарство-елеватор».

Модель нейронних мереж надає можливість зробити раціональним прийняття управлінських рішень та сприяти інтелектуалізації логістики ланцюгів поставок 3 метою мінімізації операційних витрат для перевезення вантажу. Тобто планувати та негайно виконувати розподіл залежно від попиту на вантаж. Ця модель враховує такі параметри як сезонність або нерівномірність перевезень, рух транспортних засобів та інфраструктуру залізниці. Особливо доцільним використання цієї моделі буде на етапі транспортування «елеватор-лінійний елеватор/морський термінал» із залученням залізничного транспорту.

Особливістю нечіткої моделі управління $є$ те, що вхідні параметри описуються не кількісним значенням, а певною терм-множиною. При цьому кількісні характеристики представляються нечітко та у вигляді лінгвістичних змінних.

Дослідження попиту на вантажні перевезення дозволить підвищити ефективність на різних етапах доставки. Кожна наведена модель має особливий підхід до дослідження попиту та прогнозування перевезень у аграрному секторі. Проте створення уніфікованої моделі прогнозування попиту на перевезення сприятиме раціоналізації прийняття управлінських рішень та мінімізації витрат на кожному з етапів транспортування зернових культур, що сприяє подальшим дослідженням.

Ключові слова: зернові культури, попит на перевезення, модель штучних нейронних мереж, імітаційна модель, нечітка модель управління.
\end{abstract}

\section{ВСТУП}

Зростання аграрного сектору в Україні за останні роки не могло не відобразитись на логістиці зернових культур. За даними Державної служби статистики України у 2019 році обсяги перевезень зернових культур автомобільним транспортом зросли на 16,1\% - до 22,4 млн тонн, без урахування діяльності фізичних осіб. За оцінкою компанії Pro-Consulting, що проводить маркетингові дослідження ринків, обсяг перевезення автомобільним транспортом у 1,5-2 рази більший та може складати від 33 млн до 40 млн тонн. В той час, перевезення Укрзалізницею зросли на 23,2\% та досягли рекордного значення за останні чотири роки - 40,5 млн. т. та 4,9 млн тонн зернових і продуктів перемолу - на 54\% більше порівняно 2018 роком водним транспортом [1].

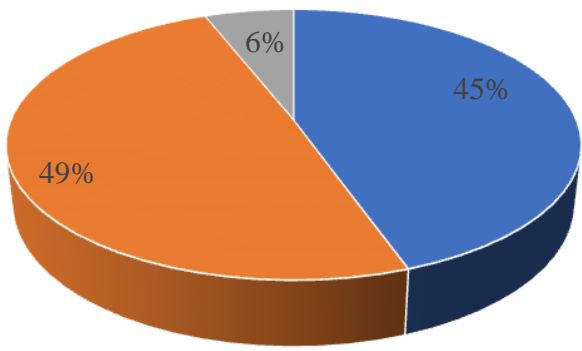

- Автомобільний транспорт - Залізничний транспорт = Водний транспорт

Рисунок 1. Структура перевезень зернових культур за типом транспорту у 2019 році

Iз структури, представленої на Рисунок 1, спостерігаємо досить високі показники автомобільних перевезень у ланцюгах поставок зернових культур, що підтверджує доцільність подальших досліджень. 


\section{АНАЛІЗ ЛІТЕРАТУРНИХ ДАНИХ ТА ПОСТАНОВКА ПРОБЛЕМИ}

Попит на зерно та пов'язану з ним діяльність формує попит на його транспортування. Оцінити попит на сільськогосподарські перевезення необхідно для аналізу транспортної політики та прийняття рішень про господарську діяльність перевізників.

Загальне поняття попиту на перевезення вантажів відображає кількість потреб у перевезеннях та додаткових транспортних послугах відповідно до ціни та обсягу. Кількісна оцінка на будь-який вид транспортних послуг розраховується після визначення меж транспортного ринку, на якому здійснюється або планується транспортна діяльність [2].

Попит на транспортні послуги можна визначити за такими методами:

•прямий розрахунок - визначається для кожного виду послуг. Розраховується множенням фактичного обсягу виробництва транспортних послуг на коефіцієнт росту ринку і на коефіцієнт повторності перевезень періоду, що передує розрахунку. Коефіцієнт росту визначається за даними експертів або власними дослідженнями;

•експертний - розраховується як середня оцінка по групі експертів і представляється як імовірнісна характеристика;

•експериментальний - визначається вимірюванням фактичного обсягу попиту за допомогою опитувань різних груп і суб'єктів ринку (клієнтів, посередників);

•математичний - найбільш точний, трудомісткий та структуризуючий. Передбачає аналіз ряду статистичних даних, даних обліку державних довідників.

Особливостями попиту автотранспортної діяльності є:

-нерівномірність попиту у часі і просторі за рахунок сезонності перевезень, структури вантажопотоків, структури споживання, якості і рівня споживачів, рівня технологічного розвитку;

•вторинність виникнення транспортного попиту, що задовольняється за допомогою транспорту.

Зазначені моделі дозволяють визначити попит на вантажні перевезення, що, в свою чергу, сприяє підвищенню ефективності доставки на різних етапах ланцюга поставок зернових культур та оптимізації управлінських рішень. Кожна наведена модель має особливий підхід до дослідження попиту та прогнозування перевезень у аграрному секторі.

\section{ЦІЛІ ТА ЗАДАЧІ ДОСЛІДЖЕННЯ}

Метою дослідження $є$ аналіз моделювання ланцюгів поставок у аграрному секторі, що враховують попит на транспортування. Систематизація отриманих результатів дозволить всебічно оцінити попит та сприятиме подальшим дослідженням для формування оптимальної моделі попиту на різних етапах ланцюга поставок зернових культур.

\section{РЕЗУЛЬТАТИ ДОСЛІДЖЕНЬ}

Серед вітчизняних науковців, які досліджували моделювання попиту на основі заявки на транспортне обслуговування варто виокремити В.С. Наумова [3], А.В. Іванченка [4], Я.В. Літвінову [5]. Результати їхніх досліджень визначили, що попит на транспортне обслуговування - це потреба клієнта в послугах, підкріплена купівельною спроможністю й представлена на ринку для іiі задоволення. Елементарною одиницею, що формує попит, є заявка. Заявка на обслуговування $\epsilon$ підставою й причиною взаємодії між елементами логістичної системи доставки вантажів експедитором, перевізником, вантажним терміналом і вантажовласником. Сукупність потенційних і реальних заявок на послуги підприємства утворюють попит на його послуги, відповідно, сукупність заявок на послуги всіх підприємств регіону являє собою попит на транспортні послуги в регіоні. Кожна заявка може бути кількісно оцінена набором показників, найбільш важливими 3 яких є обсяг партії вантажу, відстань доставки й інтервал надходження заявки. Оскільки сукупність послідовних заявок на послуги транспортних підприємств характеризує попит, то завдання оцінки попиту на транспортне обслуговування перетворюється в завдання визначення параметрів потоку [5].

Імітаційна модель транспортного процесу перевезення сільськогосподарських продуктів, розроблена Сидорчуком О. В., Боярчуком В. М., Кригульом Р. Є. [6], базується на дослідженні заявок. У моделі транспортного процесу використані такі показники як: кількість заявок, що надходять 3 окремого населеного пункту; обсяги надходження вантажу в окремо взятій заявці; інтенсивність надходження заявок по днях впродовж сезону заготівлі. Моделювання здійснюється за такими етапами:

1) обгрунтування обсягу дії приймального пункту;

2) визначення показників ефективності функціонування системи для різних конфігурацій парку автомобілів; 
3) на підставі мінімальних питомих зведених витрат функціонування- обгрунтовують оптимальний варіант.

У сучасних дослідженнях зарубіжних [7] та вітчизняних [8] науковців зустрічаємо моделювання попиту на основі штучних нейронних мереж (ANN- від англ. artificial neural network). Штучні нейронні мережі призначені для наслідування поведінки людини при прийнятті рішень через навчальні процеси. Крім того, вони є стійкими до відмов, та можуть отримувати корисні результати навіть 3 неповного набору даних. ANN розроблені для вирішення динамічних задач та не підходять для класичних задач. Вони навчаються 3 ситуацій, які вже траплялись (історичні дані) та мають на меті вирішувати проблеми, пов'язаних з розпізнаванням образів і прогнозування майбутніх значень відповідно до минулих випадків.

Основною перевагою моделей нейронних мереж є лінійність, тобто здатність встановлювати взаємозв'язок між майбутніми та фактичними значеннями процесів. До недоліків ANN відносимо відсутність прозорості в моделюванні, складність вибору архітектури, високі вимоги для послідовності навчальної вибірки, складність вибору алгоритму навчання та ресурсомісткість процесу навчання мережі [7].

Такі науковці як Гурнак В., Волинець Л., Халацька I. [8] здійснили прогнозування транспортування зернових завдяки структурній моделі на основі ANN. Цей метод прогнозування має високі властивості адаптації до змінних вхідних даних шляхом самостійного навчання моделі. Нейронна мережа може імітувати функцію практично будь-якого ступеня складності. Для того, щоб на виході нейрона отримати прогнозоване значення обсягів, автори застосовують функцію витрат на перевезення вантажу (1), що враховує наступні змінні:

$$
C\left(x_{i j}\right)=\sum_{i=1} \sum_{j=0} x_{i j} \times k_{\mathrm{H}} \times \delta_{\text {зав }} \times d_{i j}^{\text {3ав }}+\sum_{i} \sum_{j} x_{i j} \times k_{\mathrm{H}} \times \delta_{\text {пор }} \times d_{i j}^{\text {пор }}+\Delta D / \Delta x_{i j} \rightarrow \min
$$

де C - витрати на перевезення вантажу, грн .;

$x_{i j}$ - змінна кількість автомобілів, що рухаються від станції і до станції j;

$k_{\mathrm{H}}-$ коефіцієнт нерівномірного транспортування вантажів;

$\delta_{\text {зав }}, \delta_{\text {пор }}$ - частка завантажених вагонів та порожні вагонів відповідно від станції і до станції j;

$d_{i j}^{3 а в}, d_{i j}^{\text {пор }}$ - витрати, пов'язані з передачею завантажених та порожні вагони відповідно;

$\Delta \mathrm{D}$ - питомі витрати внаслідок збільшення вантажопідйомності в середньому, грн;

$\Delta x_{i j}$ - питоме збільшення кількості автомобілів транспортується від станцій і до станції $\mathrm{j}$.

Величина точності прогнозування руху визначається величиною середньої абсолютної похибки у відсотках, яка становить 5,56\% [8]. Враховуючи, що транспортна галузь $є$ досить інертною системою, такого показника достатньо для того, щоб прийняти управлінські рішення.

Дослідження попиту на перевезення зернових культур на етапі «зерновий елеватор-морський термінал» представлене у працях вітчизняних науковців Шраменко Н.Ю., Музильова Д.О. та Карнауха М.В. [9]. Запропонована нечітка модель управління планування перевезень дозволяє на основі наближених розрахунків врахувати невизначеність вхідної (що надходить) інформації, представленої у вигляді нечітко визначених параметрів, обмежень і критеріїв, які виводяться 3 детального аналізу технології оперативного планування перевезеннями. Модель має два вхідних параметри:

1)очікувані темпи зміни попиту на перевезення сільськогосподарського вантажу в плановий період, т;

2)оптимальний рівень завантаження рухомого складу;

та управлінське рішення, спрямоване на формування раціональної структури парку автомобілів на оперативний період планування на виході моделі.

Для аналізу попиту застосовують показник швидкості зміни попиту, який визначається, як очікувані темпи зміни даного показника на перевезення зерна в інтервалі між прибуттям двох кораблів, тобто на період планування [10]:

$$
\Delta S D=\frac{D_{\text {after }}^{\text {sh2 }}-D_{\text {befor }}^{\text {sh1 }}}{I_{\text {sh1 }}^{\text {sh }}},(2)
$$


$D_{\text {befor }}^{\text {sh1 }}$ - фактичне значення попиту вантажопідйомність автомобілів перед прибуттям першого судна в порт, тобто на початок планування, т;

$D_{a f t e r}^{\text {sh2 }}$ прогнозне значення попиту на перевезення зерна перед прибуттям другого корабля в порт, яке визначається на підставі завантаженості терміналу зерном і тоннажності самого судна, т. Враховує тенденцію зміни попиту на перевезення;

$D_{\text {after }}^{s h 2}$ - інтервал між заходом в порт попередніх і наступних кораблів, днів.

Даний показник характеризує часовий горизонт планування перевізним процесом.

Від'ємне значення розрахунку свідчить про зниження обсягів перевезень, що призведе до зменшення кількості автомобілів або ж вантажопідйомності, а можливо двох показників одночасно. Позитивне значення попиту свідчить про збільшення перевезення зерна, що говорить про необхідність збільшення провізних можливостей парку автомобілів.

\section{ОБГОВОРЕННЯ РЕЗУЛЬТАТІВ ДОСЛІДЖЕНЬ}

Імітаційна модель дозволяє спрогнозувати параметри автомобільного парку для вивчення попиту на транспортні перевезення сільськогосподарських товарів. Підхід до моделювання попиту через оцінку заявок на перевезення може бути використаним на етапі транспортування «індивідуальне сільське господарство-елеватор».

Модель штучних нейронних мереж дає можливість зробити раціональним прийняття управлінських рішень та сприяти інтелектуалізації логістики ланцюгів поставок з метою мінімізації операційних витрат для перевезення вантажу. Тобто планувати та негайно виконувати розподіл залежно від попиту на вантаж. Ця модель враховує такі параметри як сезонність або нерівномірність перевезень, рух транспортних засобів та інфраструктуру залізниці. Особливо доцільним використання цієї моделі буде на етапі транспортування «елеватор-лінійний елеватор/морський термінал» із залученням залізничного транспорту.

Особливістю нечіткої моделі управління є те, що вхідні параметри описуються не кількісним значенням, а певною терм-множиною. При цьому кількісні характеристики представляються нечітко та у вигляді лінгвістичних змінних. Розподіл може бути як на три, так і більше категорій. Для прикладу змінній транспортного попиту на сільськогосподарські вантажі пропонують наступні терммножини: негативне істотно, негативне незначно, середне, незначно позитивне та істотно позитивне, які визначають відповідне управлінське рішення.

\section{ВИСНОВКИ}

На сьогодні постачання зернових культур перебуває на етапі активного розвитку. Дослідження попиту на вантажні перевезення дозволить підвищити ефективність на різних етапах доставки. Кожна наведена модель має особливий підхід до дослідження попиту та прогнозування перевезень у аграрному секторі. Проте створення уніфікованої моделі прогнозування попиту на перевезення сприятиме раціоналізації прийняття управлінських рішень та мінімізації витрат на кожному з етапів транспортування зернових культур, що сприяє подальшим дослідженням.

\section{ПЕРЕЛІК ДЖЕРЕЛ ПОСИЛАННЯ}

1.Перевезення зернових і продуктів перемолу всіма видами транспорту // Аграрний тиждень Україна : веб-сайт. URL: https://a7d.com.ua/novini/49262-tork-perevezennja-zernovih-produktv-peremoluvsma-vidami-transportu-zroslo-majzhe-na-chvert.html\#sel=4:1,7:46 (дата звернення: 26.10.2020).

2.Визначення попиту i пропозиції на ринку транспортних послуг : веб-сайт. URL: http://www.uaeconomic.com/ulens-330-1.html.

3.Naumov V. Modeling Demand for Freight Forwarding Services on the Grounds of Logistics Portals Data Transportation. Research Procedia, №30, 2018, pp. 324-331.

4.Іванченко А.В. Дослідження попиту на перевезення вантажів у напрямку Україна. Транспортні системи та технології перевезень : збірник наукових праць Дніпропетровського національного університету залізничного транспорту імені академіка В. Лазаряна. 2012. № 4. С. 4043.

5.Літвінова Я.В. Дослідження параметрів попиту на складування та переробку вантажів у транспортному вузлі. Транспортні системи та технології перевезень: зб. наук. пр. Дніпропетровськ, Україна: Дніпропетр. нац. ун-ту залізн. тр-ту ім. ак. В. Лазаряна. 2015. № 10. С. 75-79.

6.Сидорчук О. В. Характеристики проектного середовища в системі централізованого звезення цукрових буряків / О. В. Сидорчук, В. М. Боярчук, Р. С. Кригуль // Восточно-Европейский журнал передовых технологий. 2010. № 1(2). С. 43-45. 
7.Abraham, Emerson \& Reis, Joao \& Colossetti, Adriane \& de Souza, Aguinaldo \& Toloi, Rodrigo. Neural Network System to Forecast the Soybean Exportation on Brazilian Port of Santos. 2017. P. 83-90. 10.1007/978-3-319-66926-7_10.

8.Gurnak V., Volynets L., Khalatska I. Intellectualization of logistic supply chains on the basis of forecasting volumes of cargo transportation. 2nd International Scientific and Practical Conference "EnergyOptimal Technologies, Logistic and Safety on Transport". MATEC Web of Conferences 2019. № 294, 04013.

9.Проблеми транспортно-логістичного забезпечення в аграрній галузі: монографія / Н.Г. Бережна, О.С. Біляєва, В.А. Войтов, О.М. Горяїнов, М.В. Карнаух, А.Г. Кравцов, О.В. Кутья, Д.О. Музильов, Н.Ю Шраменко // Харків: Міськдрук, 2019. 180 с.

10.Shramenko N., Muzylyov D., Karnaukh M. The Principles of the Choice of Management Decisions Based on Fuzzy Logic for Cargo Delivery of Grain to the Seaport. International Journal of Engineering and Technology. 2018. №7. P. 211-216. 10.14419/ijet.v7i4.3.19789.

\section{REFERENCES}

1.Perevezennia zernovykh i produktiv peremolu vsima vydamy transportu // Ahrarnyi tyzhden Ukraina : veb-sait. URL: https://a7d.com.ua/novini/49262-tork-perevezennja-zernovih-produktv-peremolu-vsmavidami-transportu-zroslo-majzhe-na-chvert.html\#sel=4:1,7:46 (data zvernennya: 26.10.2020).

2.Vyznachennia popytu i propozytsii na rynku transportnykh posluh : veb-sait. URL: http://www.uaeconomic.com/ulens-330-1.html.

3.Naumov V. (2018). Modeling Demand for Freight Forwarding Services on the Grounds of Logistics Portals Data Transportation. Research Procedia. №30. 324-331.

4.Ivanchenko A.V. (2012). Doslidzhennia popytu na perevezennia vantazhiv u napriamku Ukraina. Transportni systemy ta tekhnolohii perevezen : zbirnyk naukovykh prats Dnipropetrovskoho natsionalnoho universytetu zaliznychnoho transportu imeni akademika V. Lazariana. № 4. 40-43.

5.Litvinova Ya.V. (2015). Doslidzhennia parametriv popytu na skladuvannia ta pererobku vantazhiv u transportnomu vuzli. Transportni systemy ta tekhnolohii perevezen: zb. nauk. pr. Dnipropetrovsk, Ukraina: Dnipropetr. nats. un-tu zalizn. tr-tu im. ak. V. Lazariana. № 10. 75-79.

6.Sydorchuk O. V., Boiarchuk V. M., Kryhul R. Ye. (2010). Kharakterystyky proektnoho seredovyshcha $\mathrm{v}$ systemi tsentralizovanoho zvezennia tsukrovykh . Vostochno-Evropeiskyi zhurnal peredovykh tekhnolohyi. № 1(2). 43-45.

7.Abraham, Emerson \& Reis, Joao \& Colossetti, Adriane \& de Souza, Aguinaldo \& Toloi, Rodrigo. (2017). Neural Network System to Forecast the Soybean Exportation on Brazilian Port of Santos. 83-90. 10.1007/978-3-319-66926-7_10.

8.Gurnak V., Volynets L., Khalatska I. (2019). Intellectualization of logistic supply chains on the basis of forecasting volumes of cargo transportation. 2nd International Scientific and Practical Conference “Energy-Optimal Technologies, Logistic and Safety on Transport". MATEC Web of Conferences. № 294, 04013.

9.Problemy transportno-lohistychnoho zabezpechennia v ahrarnii haluzi: monohrafiia. (2019). N.H. Berezhna, O.S. Biliaieva, V.A. Voitov, O.M. Horiainov, M.V. Karnaukh, A.H. Kravtsov, O.V. Kutia, D.O. Muzylov, N.Iu Shramenko. Kharkiv: Miskdruk. 180.

10.Shramenko N., Muzylyov D., Manukian A. (2019). Analysis of the grain market in Ukraine and the directions of the development of grain cargo transportation logistics. Технічний сервіс агропромислового, лісового та транспортного комплексів. № 18. 70-79.

\section{Kotenko. Features of demand formation in the modeling of grain supply chains.}

Intensive development of the agricultural sector of Ukraine in recent years has led to changes in the logistics of grain crops. Demand for grain and related activities forms the demand for its transportation. It is necessary to assess the demand for agricultural transportation for the analysis of transport policy and decision-making on the economic activity of carriers.

The article considers the peculiarities of the formation of demand in the models of transportation of grain crops by domestic scientists.

The simulation model allows to determine the parameters of the car fleet to study the demand for transportation of agricultural goods, based on the assessment of applications for transportation, which can be used at the stage of transportation "individual agriculture-elevator". 
The artificial neural network model provides an opportunity to rationalize management decisions and promote the intellectualization of supply chain logistics in order to minimize operating costs for cargo transportation. That is, plan and immediately perform distribution depending on the demand for cargo. This model takes into account such parameters as seasonality or uneven traffic, traffic and railway infrastructure. It will be especially expedient to use this model at the stage of transportation "elevator-linear elevator / sea terminal" with the involvement of railway transport.

The peculiarity of the fuzzy control model is that the input parameters are described not by a quantitative value, but by a certain term set. At the same time, quantitative characteristics are presented vaguely and in the form of linguistic variables.

Researching the demand for freight will increase efficiency at different stages of delivery. Each of these models has a special approach to the study of demand and forecasting of transportation in the agricultural sector. However, the creation of a unified model for forecasting the demand for transportation will help streamline management decisions and minimize costs at each stage of transportation of cereals, which contributes to further research.

Key words: grain crops, demand for transportation, artificial neural network model, simulation model, fuzzy control model.

КОТЕНКО Вікторія Ігорівна, аспірант кафедри автомобілів та транспортного менеджменту, Вінницький національний технічний університет е-mail: mialkovska.viktoria@gmail.com.

Victoria KOTENKO, Postgraduate Student of Automobiles and Transport Management Department, Vinnytsya National Technical University e-mail: mialkovska.viktoria@gmail.com.

DOI: 10.36910/automash.v2i15.390 